\author{
Alexandre Uchan \\ Uniwersytet Warszawski \\ ORCID: 0000-0002-4205-6796 \\ e-mail: a.uchan@uw.edu.pl
}

\title{
Francisa Herberta Bradleya obrona metafizyki
}

Tendencje antymetafizyczne pojawiły się już w początkach refleksji filozoficznej. Przeciw kosmologicznym i metafizycznym rozważaniom pierwszych filozofów wystąpili w V wieku sofiści na czele z Gorgiaszem i Protagorasem. Pierwszy z nich, jako solipsysta, głosił absolutną niemożność osiągnięcia ostatecznej, metafizycznej prawdy, twierdząc, że dotychczasowe rozważania na temat natury świata nawzajem sobie przecza, a zatem nie możemy dojść do całościowej prawdy o naturze kosmosu. Protagoras z kolei odrzucił pojęcie obiektywnej prawdy na rzecz twierdzenia, jakoby to człowiek był miarą wszechrzeczy, proponując tym samym relatywizm nie tylko w kwestiach moralnych, ale również w kwestiach, które dziś nazwalibyśmy metafizycznymi czy też ontologicznymi. Także sam Sokrates odrzucał rozważania metafizyczne (czy kosmologiczne) jako jałowe z uwagi na potrzeby człowieka, twierdząc, że „niczego nie może nauczyć się od drzew”, i dlatego "sprowadził filozofię z nieba na ziemię". Paradoksalnie jednak to właśnie Sokrates przyczynił się do powstania największego metafizycznego systemu starożytności - idealizmu platońskiego $^{1}$. Sokrates bowiem, prowadząc swe rozważania etyczne,

1 Trzeba jednak w tym miejscu zwrócić uwagę na fakt, który umyka wielu historykom filozofii - nauczycielem Platona rzeczywiście był Sokrates, lecz niebagatelny wpływ na myśl Platona (można wręcz uznać, że decydujący) miał 
sformułował pewne metafizyczne tezy, mające stanowić wyjaśnienie jego etyki, takie jak np. tezy o istnieniu nieśmiertelnej duszy, Boga, obiektywnego dobra czy prawdy. Tezy te jednak same potrzebowały prawdziwie metafizycznego fundamentu. Owym fundamentem stał się platoński idealizm² ${ }^{2}$. Przykład starożytnych prób przezwyciężenia czy odsunięcia metafizyki daje nam obraz pewnej stałej walki w ramach samej filozofii i konsekwencji tejże walki. Prawie w każdej epoce myśli filozofii Zachodu możemy spotkać owe antysystemowe tendencje, które zastanawiająco często prowadzą właśnie do powstawania kolejnych metafizycznych systemów.

Źródeł dzisiejszego krytycznego stosunku do metafizyki (rozumianej jako nauka o najbardziej podstawowych prawach rzeczywistości) można dopatrywać się w filozofii Davida Hume'a i jego krytyce klasycznego myślenia metafizycznego, które uznawał za jałowe, dalekie od życia, zupełnie bezużyteczne i które przeciwstawiał tzw. filozofii popularnej:

Bliżej łączy się ona [tj. filozofia popularna] z życiem, kształci serce i uczucia, a odnosząc się bezpośrednio do zasad, które kierują działaniem ludzkim, poprawia obyczaje i zbliża człowieka do doskonałych wzorów, jakie opisuje. Filozofia spekulatywna natomiast, opierając się na sposobie myślenia, który nie ma nic wspólnego z działaniem i życiem praktycznym, zatraca się, gdy filozof opuści swe ustronie i wstąpi na widownię życia [...]. Wzruszenia serca, gra namiętności, siła uczuć unicestwiają wszelkie jej tezy i sprawiaja, że uczony filozof przestaje różnić się od zwykłego prostaka ${ }^{4}$.

Parmenides z Elei. Jak zauważa Kahn, o ile spotkanie z Sokratesem uczyniło z Platona filozofa, o tyle myśl Parmenidesa uczyniła z Platona metafizyka. Zob. Charles H. Kahn, „Being in Parmenides and Plato”, w: Charles H. Kahn, Essays on Being (New York: Oxford University Press, 2009), 238. Z kolei David Gallop, podkreślając rolę Parmenidejskiej myśli w twórczości Platona, stwierdza, że sama myśl Platona stanowi przypis do eleackiej metafizyki. Zob. David Gallop, Parmenides of Elea (Toronto-Buffalo-London: University of Toronto Press, 1991), 3.

2 Oprócz Platona również inny uczeń Sokratesa, Euklides z Megary, uznał za swoje zadanie ugruntowanie Sokratejskiej etyki. Zob. Giovanni Reale, Historia filozofii starożytnej, t. 1, przeł. Edward Iwo Zieliński (Lublin: KUL, 2008), 430.

3 Ktoś mógłby twierdzić, powołując się na Badania, że sam Hume nie odrzucał metafizyki i co więcej, nie szczędził wysiłków, by ją bronić. Niemniej jednak szkocki filozof przez metafizykę nie rozumiał rozważań nad najbardziej podstawową naturą rzeczywistości, lecz raczej coś, co określał mianem „głębszych dociekań". Co więcej, wyraźnie twierdził on, że taka metafizyka ma przede wszystkim tę wartość, że za jej pomocą można wykazać, że przedmioty rozważań tradycyjnej, systemowej metafizyki są $\mathrm{w}$ istocie poza granicami naszego poznania i daje ona podporę filozofii popularnej. Zob. David Hume, Badania dotyczace rozumu ludzkiego, przeł. Jan Łukasiewicz i Kazimierz Twardowski (Warszawa: PWN, 1977), 7-16.

4 Tamże, 4-5. 
Za myślami Hume'a podążył w pewnej mierze i niebezkrytycznie Immanuel Kant, który jak sam wspominał, został przez szkockiego filozofa „przebudzony z dogmatycznej drzemki”.

Na przełomie XIX i XX wieku nasiliły się tendencje antymetafizyczne, które swój szczyt osiągnęły w XX wieku. Wielu ówczesnych myślicieli skłonnych było uważać, że metafizyka jako nauka się wyczerpała. Jednak byli i tacy filozofowie, którzy przeciwstawiali się tym trendom i kontynuowali myślenie nakierowane na budowanie metafizycznych systemów. Dlatego tak ważną postacią jest Francis Herbert Bradley, jeden $\mathrm{z}$ ostatnich wielkich reprezentantów myślenia metafizycznego i jeden z najważniejszych myślicieli idealizmu brytyjskiego ${ }^{5}$. Jednak, jak już z perspektywy czasu wiemy, owe antymetafizyczne tendencje ostatecznie wzięły górę nad filozofią systemową. Dlatego też filozofia Bradleya i właściwie cały idealizm brytyjski spotkały się z falą krytyki, która najczęściej chybiała celu i wciąż daje nam do myślenia o ówczesnej filozofii tzw. analitycznej6.

Zadowalająca analiza Bradleyowskiej koncepcji metafizyki, jak sądzę, wymaga raczej omówienia w ramach monografii aniżeli jedynie krótkiego artykułu. Dlatego też w niniejszej pracy zostanie poddana analizie tylko argumentacja Bradleya z krótkiego wstępu do jego głównego dzieła Appearance and Reality, mająca na celu dowiedzenie zasadności, jak i możliwości uprawiania metafizyki, rozumianej jako nauka o pierwszych zasadach rzeczywistości. Oksfordzki filozof, rozważając zarzuty, jakie były wysuwane w stosunku do metafizyki, a które możemy wiązać m.in. z myślą Kanta czy Hume'a, wykazuje, że w istocie chybiają one celu. Ów krótki wstęp jest tym ważniejszy, że stanowi jedyny tekst Bradleya, w któ-

5 O znaczeniu Bradleya może świadczyć fakt, że w Contemporary British Philosophy John Muirhead stwierdza, że Bradley był prawdopodobnie najwybitniejszym ówczesnym filozofem. Zob. John Henry Muirhead, Contemporary British Philosophy: Personal Statements (London: George Allen and Unwin, 1924), 11.

6 Krytyka myśli Bradleya, przeprowadzona przez takich filozofów jak Moore czy Russell, jest więcej niż chybiona i eufemizmem byłoby nazwać ją nietrafną. Niemniej jednak późniejsi filozofowie tzw. analityczni, nie bardzo przejmując się rzeczywistymi poglądami Bradleya, uznali, że krytyka Russella i Mooréa dosięgnęła celu: „For just about anyone, Moore and Russell won this battle and Bradley lost, and analytical philosophy as we have come to know it came into ascendancy. Bradley has since then been relegated to the status of an historical and philosophical footnote and is basically the object of ridicule and neglect among analytical philosophers in the know”. Zob. Michael Della Rocca, „Bradley's Appearance and Reality", w: Ten Neglected Classics of Philosophy, red. Eric Schliesser (New York: Oxford University Press, 2017), 121. 
rym systematycznie zajmuje się on zasadnością uprawiania metafizyki ${ }^{7}$. Jest tym samym jedną z ostatnich i być może najważniejszą (ze względu na postać samego Bradleya i jego czołową rolę wśród brytyjskich idealistów) apologią metafizyki, jaką wydała na świat filozofia absolutnego idealizmu. Tym bardziej zastanawiający jest fakt, że owa apologia nie została właściwie omówiona w literaturze poświęconej myśli brytyjskiego idealisty.

Jak zostanie wskazane, w perspektywie XX-wiecznej myśli, często krytycznej wobec systemowej filozofii, owa obrona metafizyki wydaje się również niejako uprzedzać zarzuty, jakie wysuwał wobec niej m.in. Emmanuel Lévinas, i jest nad wyraz aktualna. Koncepcja metafizyki, jaka wyłania się ze wstępu do Appearance and Reality, może tłumaczyć również powrót do problematyki metafizycznej, jaki nastąpił w XX wieku za sprawą tzw. zwrotu metafizycznego.

I.

We wstępie swego dzieła Bradley stwierdza, że metafizyka, jako pewna próba odkrywania najbardziej podstawowych praw rządzących rzeczywistościa, stała się przedmiotem ataku. Czasy, w jakich przyszło żyć oksfordzkiemu filozofowi, były czasami, w których poddawano krytyce nie tylko wartość metafizyki, ale również jej możliwość ${ }^{8}$. Dlatego też wstęp do Appearance and Reality poświęcony jest nie ogólnemu zarysowi systemu, lecz obronie możliwości metafizyki jako nauki. Choć Bradley nie wymienia $\mathrm{z}$ imienia i nazwiska żadnego filozofa, przeciw któremu formułuje swe poglądy, to uważny czytelnik dostrzeże, że ostrze argumentacji wydaje się wymierzone w Kanta i jego krytykę tzw. filozofii dogmatycznej, Hume'a9 ${ }^{9}$ jak i nawiązujących do nich myślicieli. Autor Appearance and

7 Późniejsze komentarze dotyczące metafizyki zawarte w Essays on Truth and Reality czy Collected Essays mają raczej charakter niezbyt rozbudowanych uwag i dygresji.

8 Nie tylko więc Bradley poczuwał się do obowiązku obrony metafizyki jako nauki. Jak niżej zobaczymy, również inni myśliciele z nurtu idealizmu brytyjskiego formułowali argumenty mające wykazać zasadność badań metafizycznych.

9 Również Thomas Hill Green uznawał tych dwóch filozofów za myślicieli, z których myślą powinniśmy się zmierzyć, by po wykazaniu ich błędów móc rozwinąć system adekwatnej metafizyki. Por. Janusz Grygieńć, Thomas Hill Green: od epistemologii do filozofii politycznej (Toruń: Europejskie Centrum Edukacyjne, 2009), 27-37. 
Reality zdawał sobie sprawę z tego, że antymetafizyczny nurt filozofii zaczął zyskiwać coraz większe znaczenie. Jak stwierdza:

Filozof piszący o problemach metafizyki ma wiele przeciwko sobie. Zajęty tematem, który bardziej niż inne wymaga spokoju ducha, zanim jeszcze uwikła się w kontrowersje na swym własnym polu, zauważy, iż wplątał się w pewnego rodzaju wojnę. Staje wobec wrogich jego badaniom poglądów i kusi go to, by się na nich oprzeć $[\ldots]^{10}$.

Jak już wspomniano, w polemice z przeciwnikami metafizyki ostrze swej krytyki Bradley wymierza (obok Hume'a) przede wszystkim w argumentację Kanta z jego pierwszej Krytyki, jakoby wiedza metafizyczna była absolutnie niemożliwa (oczywiście Kant ma na myśli metafizykę tzw. dogmatyczną ${ }^{11}$ ). Brytyjski filozof zdaje sobie jednak sprawę z tego, że wobec metafizyki wysuwano również inne zarzuty. Wymienia te, które zamierza rozważyć:

a) Wiedza metafizyczna jest całkowicie niemożliwa.

b) Wiedza metafizyczna jest teoretycznie możliwa, lecz bezużyteczna.

c) Dawne systemy filozoficzne wyczerpały możliwości metafizyki.

a) Pierwszy pogląd na teorie pierwszych zasad przytaczany przez Bradleya wydaje się w istocie zarzutem Kanta, który to metafizykę rozumiał jako rozważania o Bogu, duszy i świecie jako całości (i dodajmy, tak też rozumie ją Bradley). Argument ten, zdaniem brytyjskiego filozofa, jest ze swej natury nie do utrzymania i wewnętrznie sprzeczny. Człowiek bowiem, który twierdzi, jakoby rzeczywistość miała taką naturę, że jest ona dla nas (w całości czy jakiejś części) niepoznawalna, de facto wyraża tym samym sąd jawnie metafizyczny. Jest to zatem stanowisko człowieka, który, najprawdopodobniej nieświadomie, wkroczył już na pole rozważań

10 Francis Herbert Bradley, Zjawisko a rzeczywistość, przeł. Jerzy Szymura (Toruń: Comer, 1996), 1.

11 Warto zauważyć, że owa krytyka Kanta nie była przekonująca nawet dla filozofów często z nim wiązanych. Wartość przedkrytycznej filozofii doceniał Schelling: „Filozofia przyrody i filozofia transcendentalna rozdzieliły się zatem podług obydwu możliwych kierunków filozofii. Skoro zaś wszelka filozofia musi zaczynać od tego, aby bądź z przyrody czynić inteligencję, bądź z inteligencji przyrodę, to filozofia transcendentalna, której zadaniem jest właśnie wywiedzenie przyrody z inteligencji, stanowi druga z koniecznych podstawowych dyscyplin nauk filozoficznych". Zob. Friedrich Wilhelm Joseph Schelling, System idealizmu transcendentalnego, przeł. Krystyna Krzemieniowa (Warszawa: Wydawnictwo Naukowe PWN, 2015), 14. 
metafizycznych i jest dla metafizyka nikim innym jak konkurentem, broniącym odmiennej teorii pierwszych zasad ${ }^{12}$. Warto zauważyć, że podobny argument formułuje Thomas Hill Green przeciw (rzekomo) antymetafizycznemu sensualizmowi (m.in. Hume’a):

[...] Jest on [tj. sensualista] tak samo metafizyczny, kiedy mówi o ciele lub materii, jak kiedy mówi o sile, o sile, jak kiedy mówi o umyśle, o umyśle, jak kiedy mówi o Bogu. Wykracza poza zmysł tak samo, kiedy mówi, że może znać tylko rzeczy indywidualne lub zjawiska [fenomeny], jak wtedy, gdy twierdzi, że zna substancje i to, co uniwersalne ${ }^{13}$.

Należy również wspomnieć w tym miejscu o J. M. E. McTaggarcie, który stawał w obronie metafizyki, twierdząc, że aspiracje nauk empirycznych do zastąpienia metafizyki są skazane na niepowodzenie. McTaggart nie bez racji wskazywał, że jeśli np. fizyka rości sobie prawo do zajęcia miejsca metafizyki, jako teorii pierwszych zasad (tj. najbardziej podstawowej nauki), to twierdzenie „fizyka jest nauką o pierwszych zasadach rzeczywistości" nie jest $\mathrm{w}$ istocie twierdzeniem fizyki, jej przedmiotem bowiem jest tylko rzeczywistość fizyczna. Fizyka, która twierdzi coś o samej sobie, staje się w istocie metafizyką ${ }^{14}$.

Zasadniczą idea, stanowiąca, jak się wydaje, nić przewodnią argumentacji brytyjskich idealistów, jest to, że metafizyka jest w istocie zawsze pewnym teoretycznym tłem wszelkiej innej wiedzy, jednak nie wszyscy zdają sobie sprawę z istnienia owego tła i jego znaczenia. Jak stwierdza Bradley:

Gdybyśmy bowiem nie posiadali pojęcia tego, co jest poza wiedza, z pewnością nie wiedzielibyśmy, jak mówić o niepowodzeniu albo powodzeniu w jej zdobywaniu. Probierzem, za pomocą którego odróżniamy te dwie rzeczy, musi oczywiście być jakaś znajomość natury celu. Mało tego, rzekomy sceptyk, który gnębi nas, mówiąc, że nasze myśli są sprzeczne, sam wypowiada to twierdzenie dogmatycznie. Sprzeczności te mogłyby bowiem

12 Bradley, Zjawisko, 1.

13 Thomas Hill Green, „Popular Philosophy in Its Relation to Life”, w: Works of Thomas Hill Green, t. 3, red. Richard Lewis Nettleship (London: Longmans, Green, and Co., 1889), 95.

14 "If we assert that science is capable of assuring us of such a harmony, we assert that science can give us information of the ultimate nature of reality. For it is clear that science cannot assure us of our harmony with the universe unless it is able to tell us what is the nature of the universe. But if we assert this, then we have not got rid of dogma. The fundamental propositions of science have become metaphysical dogmas". Zob. John McTaggart Ellis McTaggart, Some Dogmas of Religion (London: Edward Arnold, 1906), 13. 
uchodzić za ostateczna, absolutną prawdę, gdyby natura rzeczywistości nie była znana jako inna ${ }^{15}$.

Jak bowiem dowieść komuś, że dany pogląd dotyczący pierwszych zasad jest błędny w momencie, gdy sami takiej wiedzy o świecie nie posiadamy? By twierdzić, że wiedza o pewnych przedmiotach jest poza naszym zasięgiem, trzeba wpierw przyjąć pewien obraz świata, w którym owe przedmioty umieszczamy poza granicami naszego poznania czy możliwej wiedzy. Ale by je tam umieścić, musimy nasz obraz świata albo uzasadnić, a nie można tego uczynić inaczej niż na drodze podawania dowodów, które ze swej natury są metafizyczne, albo (jak to niektórzy mieli w zwyczaju) po prostu arbitralnie przyjąć i obwieścić światu i metafizykom, że przedmiot ich zainteresowania znajduje się poza granicami naszego poznania. Dlatego też $\mathbf{z w}$. filozofia krytyczna, która miała być nowym sposobem ujmowania rzeczywistości ${ }^{16}$, okazuje się jedynie kolejnym systemem filozofii dogmatycznej.

b) Drugim zarzutem, jaki można wysunąć przeciwko zasadności refleksji nad pierwszymi zasadami, jest argument znany od starożytności. Już sofiści, a także Sokrates, podważali celowość rozważań metafizycznych, argumentując, że wiedza ta jest z punktu widzenia ludzkiego życia i jego celu po prostu zbędna ${ }^{17}$. Jak wspomnieliśmy na początku, pogląd ten szerzej propagował Hume ${ }^{18} \mathrm{w}$ swych Badaniach dotyczacych rozumu ludzkiego ${ }^{19}$.

15 Bradley, Zjawisko, 2. W tym miejscu stanowisko Bradleya może wydawać się podobne do tego, jakie zajmuje już Platon w swym dialogu Menon, gdzie broniąc teorii anamnezy, dowodzi, że aby zdobyć jakąkolwiek wiedzę, musi posiadać już jakiś jej cień. Należy jednak zaznaczyć, że zdaniem brytyjskiego filozofa nasze pojęcie tego, co jest poza wiedza, a co nie, wynika przede wszystkim z kryterium niesprzeczności, jakie narzuca się naszemu umysłowi, a nie z intuicyjnego posiadania jakiejś prawiedzy.

16 O znaczeniu metafizyki u Kanta zob. Ewa Wyrębska, „Idea metafizyki w filozofii Immanuela Kanta", Diametros 23 (2010).

17 William James, zagorzały krytyk filozofii Bradleya, podkreślał, że wartość ma jedynie ta filozofia, która realnie wpływa na naszą praktykę, na to, jak postępujemy w naszym życiu. Zob. William James, Doświadczenia religijne, przeł. Jan Hempel (Warszawa: Książka i Wiedza, 1958), 402-403.

18 Oczywiście pamiętajmy, że Hume ma tu na myśli metafizykę systemowa, nakierowaną na poznanie podstawowych praw całej rzeczywistości, którą przeciwstawia zdrowemu rozsądkowi i filozofii popularnej.

19 Co ciekawe, również filozof stricte metafizyczny, jakim był Berkeley, mimo że nie odrzucał metafizyki, to pomstował na tych filozofów, których rozważania nie miały żadnej praktycznej wartości, i sam podkreślał praktyczną wartość swego 
Jak zauważa Bradley, zarzut ten może opierać się na różnych podstawach, dlatego też warto przytoczyć przynajmniej najważniejsze z nich i poddać je analizie:

1. Pierwszy sposób argumentowania opiera się na przekonaniu, że niejako na "terenie" metafizyki panuje niezmierny chaos i jałowość - ciągle poruszamy się $\mathrm{w}$ obrębie tych samych problemów i wciąż, mimo tak licznych dyskusji, nie możemy ich rozwiązać. Dlatego też powinniśmy ją porzucić i zająć się czymś, co bardziej zasługuje na nasz trud.

Odpowiedź Bradleya na taką argumentację może wydać się dzisiejszemu czytelnikowi dość zaskakująca. Uważa on bowiem, że metafizyka nie jest nauką stateczna, lecz rozwija się (a czasem cofa) podobnie jak ludzka natura, a zatem i jej problematyka nie jest ciągle ta sama. Odrzucając przekonanie o stałości metafizyki, możemy więc uznać, nie przesądzając o możliwości osiągnięcia adekwatnej wiedzy o pierwszych zasadach, że warto zaryzykować takie rozważania - oczywiście pod warunkiem, że ktoś znajduje upodobanie $\mathrm{w}$ tego typu refleksji ${ }^{20}$. Przeciwnik może wprawdzie argumentować, że wielu wybitnych filozofów podejmowało trud stworzenia adekwatnej teorii pierwszych zasad z mizernym skutkiem. Jak jednak zauważa brytyjski filozof:

[...] Człowiek, który odnosi sukces, najwyraźniej nie zawsze jest człowiekiem największych zasług i nawet w zimnym świecie filozofii sprzyjać może ślepy los. Nikt nie wie, czy mu się uda, dopóki nie spróbuje ${ }^{21}$.

Należy w tym miejscu zaznaczyć, że autor Appearance and Reality nie uważa, by pełna wiedza o pierwszych zasadach była możliwa. Mamy co prawda wiedzę o Absolucie, która jak powiada Bradley, , jest rzeczywista i niezawodna", jednak w swych metafizycznych dociekaniach jesteśmy skazani jedynie na niepełną satysfakcję ${ }^{22}$. Mimo to fakt, że nie jesteśmy zdolni do osiągnięcia całościowej wiedzy o rzeczywistości, nie oznacza bynajmniej, że jest ona bezwartościowa. A jest tak, ponieważ sama natura ludzka domaga się tego, by myśleć o wszechświecie. Dotyczy to każdego człowieka, gdyż świat i los, jakie przypadły mu w udziale, są niejako naturalnym przedmiotem jego myśli. Dlatego, zdaniem Bradleya, zasadnym pytaniem nie jest to, "czy powinniśmy myśleć o wszechświecie”, skoro i tak niejako mimowolnie to robimy, lecz w jaki sposób powinniśmy to

immaterializmu. Zob. George Berkeley, Trzy dialogi między Hylasem a Filonousem, przeł. Janina Sosnowska (Kęty: Antyk, 2002), 92.

20 Bradley, Zjawisko, 3.

21 Tamże.

22 Tamże. 
robić ${ }^{23}$. Jedyne, czego domaga się metafizyka, to jej uczciwe i sumienne uprawianie, „na ile pozwala nam na to nasza natura” ${ }^{24}$. Dlatego też przeciwnik metafizyki staje przed dylematem: albo $(\alpha)$ postulując zaniechanie refleksji metafizycznej, stara się zerwać $\mathrm{z}$ „najwznioślejszą stroną ludzkiej natury", albo też ( $\beta$ ) pozwala nam myśleć o świecie, lecz nie pozwala nam robić tego w sposób ścisły i dokładny:

Zakrawa to na paradoks, ponieważ zdaje się mówić: Możesz zadowalać swoje instynktowne pragnienie refleksji tak długo, jak długo robisz to w sposób, który jest niezadowalający ${ }^{25}$.

Jest to oczywisty i jasny argument przeciw Kantowi. Kant bowiem, podobnie jak Bradley, uważa, że myślenie metafizyczne jest nieodłączną częścią ludzkiej natury ${ }^{26}$. W tej optyce myśl Kanta wikła się w pewne sprzeczności - z jednej strony filozof przyznaje, że człowiek nie może uciec od metafizycznych pytań (o Boga, duszę czy świat jako całość), z drugiej uznaje, że nie powinien on się nimi skrupulatnie zajmować.

2. Jak dalej zauważa Bradley, zwolennik tego poglądu na metafizykę może jednak twierdzić, że mimo faktu, iż metafizyka jako działalność intelektualna jest uprawniona, to ze względu na jej niezadowalające rezultaty nie mamy powodów, by uważać ją za refleksję pożądaną. Odpowiadając na te wątpliwości, Bradley stwierdza, że badania metafizyczne nie są odpowiednie dla każdego ${ }^{27}$ i nawet jeśli takie rozważania nie przynosiłyby nam żadnych konkluzywnych rezultatów, to są o tyle ważne, iż stanowią dla nas narzędzie do walki z wszelkim dogmatyzmem, w tym religijnym ${ }^{28}$,

23 Tamże.

24 Warto w tym miejscu wspomnieć, że w swych Badaniach dotyczacych rozumu ludzkiego Hume stawiał klasycznej metafizyce zarzut, że jest ona niejako osłoną dla pewnych dogmatycznie przyjmowanych zabobonów. Zob. Hume, Badania, 10.

25 Bradley, Zjawisko, 4.

26 Zob. Immanuel Kant, Krytyka czystego rozumu, t. 1, przeł. Roman Ingarden (Warszawa: PWN, 1986), 26.

27 Bradley, Zjawisko, 4. Kwestia egalitarności czy też elitarności filozofii, a w szczególności metafizyki, była już przedmiotem zainteresowania pierwszych filozofów. Parmenides w swym poemacie $O$ naturze wyraźnie rysował opozycję między człowiekiem oddanym rozważaniom nad naturą bytu a dwugłowymi (gr. dikranoi), tj. ludźmi nieoddanymi takim rozważaniom. Podobnie Heraklit stawiał mocną granicę między tymi, którzy rozumieją boski logos, a barbarzyńcami niesłyszącymi tegoż. Również Sokrates uważał, że „tylko niektóre dusze są brzemienne w prawdę", co było, jak się wydaje, dla Platona myślą przewodnią w jego koncepcji tego, czym jest filozofia.

28 Tamże, 5. Jak stwierdza Bradley, chodzi tu głównie o ortodoksyjną teologię jego czasów, jak i o materializm. 
i ochronę przed nim. Idzie tym samym po części śladami Greena, który również upatrywał w religijnym dogmatyzmie (lecz nie w samej religii ${ }^{29}$ ) to, co człowieka tłamsi i zniewala ${ }^{30}$.

Dlatego też i choćby tylko z tego jednego powodu, że metafizyka jest schronieniem dla tych, którzy nie chcą być niewolnikami „nieuczciwej sofistyki" czy "tępego fanatyzmu”, warto ją uprawiać. Należy w tym miejscu zauważyć, jak szczególne z perspektywy filozofii XX wieku jest stanowisko brytyjskiego filozofa, który właśnie w metafizycznej refleksji poszukiwał ochrony przed fanatyzmem, a nie, jak chcieliby inni, w zaniechaniu takiego myślenia. To bowiem krytyczne myślenie, ciągła analiza własnego stanowiska i ruch myśli zapewniają nam schronienie przed dogmatyzmem. Bradley w tym miejscu niejako uprzedza atak na systemową metafizykę sformułowany przez Lévinasa, zdaniem którego to myśl Parmenidesa (tj. myślenie głęboko metafizyczne) doprowadziła do okrucieństw XX wieku i kryzysu kultury europejskiej ${ }^{31}$. Według Bradleya to nie to, co później Lévinas określa mianem „myślenia Parmenidesa”, prowadzi nas do fanatyzmu i dogmatyzmu, lecz właśnie jego zaniechanie. Jak stwierdza:

Taki sceptycyzm [...] może służyć [nam] [...] jako wyzwolenie z duchowego uciemiężenia. Może bowiem uwolnić nas z każdej strony od tyranii intelektualnych przesądów, a w naszych życiowych troskach od zabobonnego bałwochwalstwa abstrakcyjnej spójności ${ }^{32}$.

Metafizyka jako racjonalna refleksja nad rzeczywistościa, niejako ze swej natury, nie może prowadzić do dogmatyzmu czy ideologicznego fa-

29 Green uważał, że nauka i prawdziwa religia są w istocie ze sobą zgodne: "The human spirit is one and indivisible, and the desire to know what nature is and means is as inseparable from it as the consciousness of God and the longing for reconciliation with him. The scientific impulse on the one side, and the faith that worketh by love on the other, exhibit the same spirit in different relations. It is only some mistake that we make as to the origin or office of either that brings them into apparent competition”. Zob. Thomas Hill Green, „Faith”, w: Works of Thomas Hill Green, t. 3, red. Richard Lewis Nettleship (London: Longmans, Green, and Co., 1889), 264.

30 Choć trzeba równocześnie przyznać, że mimo iż w filozofii obu myślicieli przewodnią myślą jest utożsamienie rzeczywistości z czymś boskim, to Green zdaje się utożsamiać swą „wieczną świadomość” z chrześcijańskim Bogiem. Bradley z kolei nie mówi nic o Bogu, lecz o Absolucie, i tym samym jego krytyka „religijnego fanatyzmu” wydaje się bardziej radykalna.

31 Por. Barbara Skarga, „Emmanuel Lévinas: kultura immanencji”, w: Barbara Skarga, Tożsamość i różnica (Kraków: Znak, 1997).

32 Francis Herbert Bradley, Essays on Truth and Reality (Oxford: Clarendon Press, 1914), 445. 
natyzmu, ponieważ jej celem jest badanie rzeczywistości jako całości, a nie naginanie świata do pewnej ideologii. Strach Lévinasa przed totalitarnymi ideologiami nie pozwolił mu zauważyć, że ideologia jak zespół poglądów jest czymś istotowo innym niż system metafizyczny. Bez metafizyki bowiem sam Lévinas mógłby być posądzony o dogmatyzm. Metafizyka, jako racjonalny system pierwszych zasad, jest źródłem i fundamentem innych poglądów, w tym etycznych ${ }^{33}$. Nie mając tego oparcia, nasze poglądy etyczne albo pozostają bez uzasadnienia, albo zmuszeni jesteśmy polegać na intuicji, która często prowadzi nas właśnie w ramiona dogmatyzmu. Dlatego też Bradley tak bardzo podkreśla w swych pracach sceptyczny element metafizyki, który jest de facto jej elementem konstytutywnym. Jak zauważa Sushil Kumar Saxena: „Jako filozoficzni sceptycy wątpimy $\mathrm{w}$ to, jak rzeczy jawią się nam na pierwszy rzut oka, tylko w tym celu, by lepiej je zrozumieć" ${ }^{34}$.

Ostatecznie okazuje się, że metafizyka w tej optyce, wbrew twierdzeniom Hume'a, nie jest nie tylko czymś niepotrzebnym i zbędnym człowiekowi w jego życiu, lecz co więcej, jest czymś, co łączy się ,,[...] z życiem, kształci serce i uczucia" ${ }^{35}$.

c) Ostatni zarzut przeciw uprawianiu metafizyki, jaki omawia Bradley, opiera się na przekonaniu, że nie możemy powiedzieć już nic więcej, niż powiedziały nam dawne filozofie. Zdaniem brytyjskiego filozofa, o ile dyskusyjne jest to, czy mamy do czynienia z postępem $\mathrm{w}$ filozofii, o tyle dość przekonujące wydaje się stwierdzenie, że mamy do czynienia ze zmianami w samych ludziach, a „zmieniające się umysły z każdym po-

33 O relacji między moralnością, religią i filozofią zob. Bradley, Essays, rozdz. I, XV.

34 Sushil Kumar Saxena, Studies in the Metaphysics of Bradley (London: George Allen \& Unwin Ltd.; New York: Humanities Press Inc., 1967), 25. W kontekście Bradleyowskiej metody Leemon B. McHenry słusznie zauważa, że wskazuje ona na pokrewieństwo myśli oksfordzkiego filozofa z myślą eleatów: „Bradley's dialectic, on these points, has a definite affinity to the ancients, Parmenides and Zeno. The common end sought is permanence and a vision of reality as One". Zob. Leemon B. McHenry, Whitehead and Bradley: A Comparative Analysis (Albany: State University of New York Press, 1992), 15.

$35 \mathrm{Na}$ fakt, że filozofia ostatecznie zawsze pozostaje czymś, co jest realizacją tylko jednej części naszej natury, i musi ona tym samym uwzględniać całość tego, czym jest człowiek, Bradley zwraca uwagę $\mathrm{w}$ Essays on Truth and Reality: „A true philosophy must accept and must justify every side of human nature, including itself. Like other things it has its place in that system where at once every place and no place is supreme. The mastery of that system in thought, however far we carry it, leaves philosophy still the servant of an order which it accepts and could never have made". Zob. Bradley, Essays, 14. 
koleniem będą domagały się czegoś odmiennego"36. Dlatego też, podobnie jak w każdej epoce odnajdujemy jej własną poezję, tak i mamy filozofię odpowiadającą człowiekowi będącemu dzieckiem danej epoki ${ }^{37}$. Jest to myśl, która może sugerować pewien wpływ, jaki na Bradleya miał Hegel czy szerzej rzecz ujmując, heglizm. Taki pogląd nie był wśród myślicieli idealizmu brytyjskiego odosobniony. U Greena znajdujemy przekonanie o porządku, w jakim pewne doktryny filozoficzne powstawały i ginęły, i - co więcej - twierdzenie o koniecznym charakterze tego procesu $^{38}$. Sam Bradley nie posuwa się tak daleko jak Green, lecz wyraźnie uznaje razem z nim, że filozofia jest wyrazem pewnego ducha epoki i dzięki temu duchowi może się rozwinąć. Jednak w kontekście XX-wiecznej filozofii, która zaniechała refleksji metafizycznej, być może powinniśmy uznać, że najwyraźniej metafizyka nie jest już tym, co do nas przemawia, a w związku z tym koniec metafizycznej refleksji jest uprawniony. Bradley wydaje się jednak nie dostrzegać tego zagrożenia. Wynika to prawdopodobnie z faktu, że (być może nieświadomie) utożsamia on samą filozofię z metafizyką ${ }^{39}$.

36 Bradley, Zjawisko, 6.

37 Tamże. Należy jednak zaznaczyć, że Bradley nie stoi na stanowisku, że nie możemy oceniać systemów pod kątem ich adekwatności w opisie rzeczywistości, jak twierdził Heidegger, mówiąc: „Filozofia Hegla nie jest doskonalsza od filozofii Kanta. Każda epoka filozofii ma swą własną konieczność. Każda filozofia jest, jaką jest - i ten fakt musimy po prostu uznać. Nie mamy jednak prawa przedkładać jednej filozofii nad druga, tak jak to można robić z różnymi światopoglądami”. Zob. Martin Heidegger, „Koniec filozofii i zadanie myślenia”, przeł. Krzysztof Michalski, Teksty: Teoria Literatury, Krytyka, Interpretacja 4-5 (1976): 10. Metafizyka jest, zdaniem Bradleya, pewnym wyrazem ducha epoki, lecz nie jest tylko tym, i możemy, czy wręcz powinniśmy, oceniać i porównywać różne systemy.

38 Por. Grygieńć, Thomas Hill Green, 28.

39 Podobne utożsamienie metafizyki i filozofii możemy znaleźć w myśli Heideggera. Zob. Heidegger, „Koniec filozofii i zadanie myślenia”: 9. Jednak Heidegger ma do tego utożsamienia ambiwalentny stosunek, jako że jego zdaniem: „Przedstawiając stale byt jako byt tylko, metafizyka nie myśli o samym byciu. Filozofia nie skupia się na swoim podłożu. Stale odchodzi od niego i właśnie poprzez metafizykę [...]. Myśl, która myśli o prawdzie bycia, nie zadowala się już wprawdzie metafizyka, lecz również nie myśli przeciw metafizyce. Mówiąc obrazowo, nie wyrywa korzenia filozofii. Okopuje dla niego ziemię, orze glebę. Metafizyka pozostaje tym, co pierwsze w filozofii. Nie dosięga tego, co pierwsze w myśli. W myśleniu o prawdzie bycia metafizyka zostaje przezwyciężona. Tracą moc jej pretensje do panowania nad podstawowym związkiem $\mathrm{z}$ «byciem» i miarodajnego określania wszelkiego stosunku do bytu jako takiego. Jednak takie "przezwyciężenie metafizyki» nie likwiduje metafizyki". Zob. Martin Heidegger, „Czym jest metafizyka? - wprowadzenie”, przeł. Krzysztof Wolicki, w: Budować, mieszkać, myśleć, red. Krzysztof Michalski (Warszawa: Czytelnik, 1997), 60. 
Wstęp swego dzieła Bradley kończy dość zaskakującym, w kontekście treści samego Appearance and Reality, ostrzeżeniem, jakie kieruje w stronę swoich czytelników. Otóż człowiek uprawiający metafizykę powinien wystrzegać się przekonania, że zajmuje się czymś o wiele wyższym i wznioślejszym niż jakikolwiek inny człowiek, ponieważ takie przekonanie opiera się na nieuprawnionym twierdzeniu, że to intelekt jest najwznioślejszą stroną ludzkiej natury ${ }^{40}$. Takie postawienie sprawy przez Bradleya wydaje się wielce zastanawiające w kontekście jego twierdzeń, jakoby metafizyka miała być lekarstwem na dogmatyzm, który grozi nam w naszych rozważaniach dotyczących natury świata. Brytyjski filozof wydaje się tu nie w pełni konsekwentny, lecz owa przestroga przed popadaniem $w$ kult rozumu znajduje uzasadnienie w samej filozofii Bradleya i jest niejako jej konieczną konsekwencją. Rozum z konieczności stawia przed naszym poznaniem takie warunki, jakich sam spełnić ostatecznie nie może ${ }^{41}$. Dlatego też niektórzy określali metafizykę Bradleya mianem mistycznej, jako że wskazuje ona, iż zaspokojenie naszych poznawczych (i egzystencjalnych) potrzeb odnajdujemy ponad tym, co czysto dyskursywne ${ }^{42}$. Ostatecznie okazuje się, że konsekwentna metafizyka przekonuje, że ludzka natura dalece przekracza to, co intelektualne, i dyskursywną myśl. Ograniczenie się jedynie do tego, co czysto intelektualne, jest czymś, co wykrzywia ludzką naturę. Jak zauważa Bradley, niejednokrotnie taka filozofia rościła sobie zbyt wiele i w konsekwencji zmieniała się w religię,

40 Bradley, Zjawisko, 6.

41 Zdaniem Bradleya nasze myślenie jest myśleniem zawsze dyskursywnym, które jako takie jest zawsze relacyjne i wprowadza w Jednię rzeczywistości pewną wielość, której tam rzeczywiście nie ma. Wynika to oczywiście ze stosunku Bradleya do pojęcia relacji. Sądził on, że relacje są w istocie czymś nierzeczywistym (formułuje przeciw istnieniu relacji sławny argument $\mathrm{z}$ regresu znany jako regres Bradleya) i są jedynie naszym ułomnym sposobem poznania. Myśl więc jako relacyjna nigdy nie może ostatecznie uchwycić nierelacyjnej całości. Stosunek Bradleya do naszego intelektualnego poznania dobrze wyjaśnia Peter Hylton: „The ideal of thought, and the goal towards which it tends, is thus a holistic system of knowledge in which everything would be related to everything else, and nothing excluded. This ideal is not one that Bradley believes we can in fact realize. More importantly, he holds that even if realized it would still not be wholly satisfactory because even a complete system of thought is still a system of thought, and thus confined to the content of experience, and unable to do justice to the immediacy of its existence". Zob. Peter Hylton, Russell, Idealism, and the Emergence of Analytic Philosophy (Oxford: Clarendon Press, 1992), 52.

42 Jak zauważa Saxena: „,...] It seems safe to say of AR [Appearance and Reality] that, though the epistemology is sceptical, the ontology is mystical'". Zob. Saxena, Studies, 18. 
która chciała determinować całość życia jej wyznawców ${ }^{43}$. Niemniej jednak treść samego Appearance and Reality stanowi jedną z największych pochwał możliwości i dokonań rozumu ludzkiego, a sam Bradley będzie podkreślał, że wnioski, jakie wypływają z jego rozważań nad rzeczywistością, są absolutnie niepowątpiewalne ${ }^{44}$.

II.

Idealizm brytyjski, mimo wielkiej mocy oddziaływania, nigdy nie był nurtem w brytyjskiej filozofii liczebnie dominującym. Nieugiętość i wewnętrzna spójność poglądów oksfordzkiego filozofa, jednoznacznie przywodząca na myśl eleacką dialektykę ${ }^{45}$ i słynne paradoksy Zenona z Elei ${ }^{46}$, wydają się w kontekście XX wieku i jego antymetafizycznych $i$ antysystemowych tendencji co najmniej archaiczne. Jednak owa archaiczność, gdy przyjrzeć się jej uważniej, okazuje się w zaskakujący sposób odpowiadać na problemy, jakie postawiła przed filozofią nowoczesność. Fanatyzm, ideologiczne zaślepienie nie wynikaja, jak widzieli to niektórzy, z myślenia systemowego, lecz raczej, na co wskazuje Bradley, z zaniechania takiego myślenia, które ze swej natury jako racjonalnej refleksji opartej na swoistym filozoficznym sceptycyzmie jest przeciwstawne wszelkiemu dogmatyzmowi.

Bradley do końca swego życia pozostawał główną postacią brytyjskiej myśli filozoficznej. Ataki na jego stanowisko przeprowadzane przez takich

43 Jak stwierdza: „I do not forget that philosophy has often been made into a religion. From time to time it has been taken as the one thing needful, as the end and rule of our lives, and as all the world to its worshippers". Zob. Bradley, Essays, 13.

44 Bradley w Appearance and Reality swe stanowisko podsumowuje następująco: „With regard to the main character of that Absolute our position is briefly this. We hold that our conclusion is certain, and that to doubt it logically is impossible. There is no other view, there is no other idea beyond the view here put forward. It is impossible rationally even to entertain the question of another possibility". Zob. Bradley Francis Herbert, Appearance and Reality (London: George Allen \& Unwin Ltd., 1916), 518.

45 Jak zauważa John Passmore, dialektyka Bradleya jest raczej dialektyką Parmenidesa i Zenona z Elei niż Hegla. Zob. John Passmore, A Hundred Years of Philosophy (London: Duckworth Books, 1917), 59.

46 Janusz Golichowski, opisując słynny regres Bradleya, stwierdza, że: „[...] Bez trudu można dostrzec podobieństwo tej argumentacji do znanych rozumowań eleatów”. Zob. Janusz Golichowski, „Francis Herbert Bradley a problem wewnętrznych i zewnętrznych relacji", Gdańskie Zeszyty Humanistyczne 8 (1965): 181. 
myślicieli jak George Edward Moore ${ }^{47}$ czy Bertrand Russell wydawały się (póki żył sam Bradley) świadczyć raczej o nieznajomości atakowanego stanowiska i braku naukowej rzetelności niż o problemach samego idealizmu ${ }^{48}$. Russell wielokrotnie dawał przykład głębokiej nieznajomości krytykowanej filozofii, co jednak nie odwiodło go od krytykowania tejż $\mathrm{e}^{49}$. Również, jak wskazują osoby zaznajomione z myślą idealizmu brytyjskiego, słynny tekst Moore'a Refutation of Idealism, mający na celu podważenie zasadności stanowiska idealistycznego, wydaje się atakować nie tyle sam idealizm, ile pewne wyobrażenie o idealizmie, jakie żywił autor Principia Ethica ${ }^{50}$.

Skłonny jestem uważać, że zmierzch idealizmu brytyjskiego związany jest głównie z faktem, iż duża część filozofów (szczególnie tzw. anali-

47 Co ciekawe, za pierwszy tekst Moore'a, który podejmuje polemikę z myślą idealizmu brytyjskiego, uznaje się opublikowany w 1899 roku The Nature of Judgement. Jednak stanowisko Moore'a przedstawione w tym tekście wydaje się dalej nosić znamiona myśli idealistycznej.

48 Zob. Francis Herbert Bradley, "A Discussion of Some Problems in Connexion With Mr. Russell's Doctrine", w: Bradley, Essays, 293-309.

49 Sam Russell w The Monistic Theory of Truth twierdzi, że „dokładał wszelkich staran", by zrozumieć idealistów i ich stanowisko. Zob. Bertrand Russell, „The Monistic Theory of Truth", w: Bertrand Russell, Philosophical Essays (London: Green \& Co., 1910), 152. Niemniej jednak, jak celnie zauważa Szymura, sam Russell przyznał w prywatnym liście do Bradleya, że nie studiował Appearance and Reality nazbyt dokładnie. Por. Jerzy Szymura, „O tym, jak Bertrand Russell rozprawił się z absolutnym monizmem", Studia Filozoficzne 2-3 (1990): 280.

50 Zob. Thomas Baldwin, „Moore's Rejection of Idealism”, w: Philosophy in History: Essays on the Historiography of Philosophy, red. Richard Rorty, Jerome B. Schneewind, Quentin Skinner (Cambridge: Cambridge University Press, 1984). Jak stwierdza Stewart Candlish, komentując wartość Moore'owskiej argumentacji: „It may help to add some brief reminder of how unsatisfactory even the best known of those arguments are. Consider, for example, Moore's famous article 'External and Internal Relations' (Moore 1919). Quite apart from the issue on which I have laid so much stress, that of whether Moore even chose the right target in attacking the doctrine of internality, in the whole paper, despite its length and complexity, Moore's only direct argument against this doctrine was this: 'It seems quite obvious that in the case of many relational properties which things have, the fact that they have them is a mere matter of fact: that the things in question might have existed without having them'. Similarly, Moore's sole direct argument against idealism in 'The Refutation of Idealism' (1903) was: 'I am suggesting that the Idealist maintains that object and subject are necessarily connected, mainly because he fails to see that they are distinct, that they are two, at all.' It is not always observed that the tendency to question-begging so noticeable in 'A Defence of Common Sense' (Moore 1925) and 'Proof of an External World' (Moore 1939) was there in 1903 as well”. Zob. Stewart Candlish, Russell-Bradley Dispute and its Significance for Twentieth Century Philosophy (New York: Palgrave Macmillan, 2007), 176. 
tycznych) swą wiedzę o nim czerpała i nadal czerpie właśnie z tekstów Russella, Moore'a czy, co jeszcze gorsze, z tekstów myślicieli neopozytywistycznych takich jak Alfred Ayer ${ }^{51}$, które to teksty nie są jakimkolwiek wartościowym źródłem wiedzy o filozofii autora Appearance and Reality. Znamienny jest również fakt, że początek końca ${ }^{52}$ panowania idealizmu brytyjskiego wydaje się zbiegać $\mathrm{w}$ czasie ze śmiercią samego Bradleya ${ }^{53}$. Niemniej jednak, zaznajomiwszy się z pracami oksfordzkiego filozofa, można bez problemu zdać sobie sprawę z tego, że owa zbieżność nie jest przypadkowa. Prześledziwszy tok myśli Bradleya, zawarty w jego głównym dziele, można uznać, że póki żył i był w stanie bronić swego stanowiska, tzw. nowy realizm Moore'a i Russella ${ }^{54}$ pozostawał w cieniu jego filozofii ${ }^{55}$.

Filozofia Bradleya, nie tylko w swej metafizyczno-systemowej części, ale również w jej części metafilozoficznej, wydaje się nad wyraz aktualna. Brytyjski filozof swymi rozważaniami niejako uprzedzał XX-wieczną refleksję nad samą filozofią i nad jej kryzysem, którego niewątpliwie był świadkiem. Podział w obrębie samej filozofii na paradygmat analityczny i kontynentalny wydawał się (i nadal wydaje się wielu myślicielom) wyczerpywać możliwości myślenia o filozofii. Właśnie dlatego myśl Bradleya jest tak wartościowa. Wskazuje ona filozofom trzecią drogę myślenia

51 W swym Language, Truth and Logic Ayer stwierdza, na podstawie wyrwanych z kontekstu pojedynczych zdań z Appearance and Reality, że problemem metafizyki jest to, iż tworzy ona zdania pozbawione znaczenia, a co za tym idzie - nie może ona aspirować do rangi poznania naukowego. Zob. Alfred Ayer, Language, Truth and Logic (London: Victor Gollancz Ltd., 1936), 36.

52 Warto jednak zaznaczyć, że jego dokładne datowanie jest wielce problematyczne. Jak słusznie zauważa Szymura, przejmowanie prymatu w filozofii brytyjskiej przez nowy realizm Moore'a i Russella było procesem stopniowym, który ostatecznie zakończył się dopiero po II wojnie światowej. Zob. Jerzy Szymura, Relacje w perspektywie absolutnego monizmu F. H. Bradleya (Kraków: nakł. Uniwersytetu Jagiellońskiego, 1990), 11. O zmierzchu brytyjskiego idealizmu zob. Candlish, Russell-Bradley, 174-188.

$53 \mathrm{~W}$ wydanym już po śmierci Bradleya drugim tomie Contemporary British Philosophy znajduje się następująca dedykacja: „To F.H. Bradley, Order of Merit: To whom British Philosophy owed the impulse that gave it new life in our time".

54 Należy jednak zaznaczyć, że zarówno Moore, jak i Russell nie odrzucali metafizyki jako takiej, lecz raczej tzw. metafizykę spekulatywna, i przeciwstawiali jej swą własną metafizykę. Zob. Tadeusz Szubka, "Główne typy metafizyki analitycznej", Filo-Sofija 15 (2010).

55 Jak zauważa Candlish, ani Moore, ani Russell nie uznali za zasadne odnieść się do opublikowanego po śmierci Bradleya Collected Essays: „[...] Collected Essays was published in 1935, and were comprehensively ignored". Zob. Candlish, Russell-Bradley, 3. 
o filozofii, jaka została zatracona w XX wieku. Autor Appearance and Reality postuluje, świadomy problemów nękających filozofię, nie tyle przeformułowanie naszego tradycyjnego myślenia, ile raczej jego krytyczny ogląd i powrót do pierwotnych metod i założeń filozofii. Refleksja filozoficzna nie osiągnęła swych celów, zdaniem Bradleya, nie dlatego, że same jej założenia doprowadziły do tego, iż ma ona w sobie coś, co nieuchronnie wpędza filozofów w aporie, lecz przeciwnie, problemem filozofii stało się to, że nie była ona sobie dość wierna.

Bradley powraca więc do Parmenidesa $\mathrm{w}$ tym sensie, że kontynuuje metafizykę jako poszukiwanie niesprzecznego systemu, mającego adekwatnie opisać świat, i jest głęboko nieufny wobec tego, co zwykło się nazywać zdrowym rozsądkiem ${ }^{56}$. W perspektywie XX-wiecznej filozofii, która - z jednej strony za sprawą zwrotu lingwistycznego zapoczątkowanego przez takich filozofów jak Russell czy Moore, z drugiej za sprawą wewnętrznie bardzo zróżnicowanej filozofii kontynentalnej - odrzuciła metafizykę, propozycja Bradleya wydaje się uciekać poza utarte schematy wyjaśniania niepowodzenia dotychczasowej filozofii. Jego zdaniem problemem nie jest samo myślenie metafizyczne, lecz raczej nieudolne jego uprawianie, którego nie uniknęli również filozofowie często uważani za najwybitniejszych. Słusznie możemy pytać, czy aby obydwie te drogi, którymi podążyła filozofia, nie wypaczyły samej jej istoty. Jakie jest bowiem podobieństwo między tym, co filozofią nazwał Platon, a tym, co przyniosła nam nowoczesność? Czy obecna refleksja nie odeszła już tak daleko od swych greckich korzeni, że w swej istocie przestała nią być? Nie chcę przez to powiedzieć, że refleksja ta jest bezwartościowa czy niewarta pogłębiania. Jednak wydaje się tu zasadniczym pytaniem to, czy myśl, która przestała baczyć na całość, nie przestała być tym samym filozofią ${ }^{57}$.

Jak pokazała historia, obydwie drogi, jakie zostały obrane przez większość współczesnych filozofów, nie spełniły pokładanych w nich nadziei. Szczególnie mocną krytykę współczesnej filozofii analitycznej, a dokładnie tzw. oksfordzkiej filozofii języka potocznego, przedstawił Ernest Gellner

56 Bradley pod tym względem nie jest wyjątkiem wśród innych idealistów. Idealizm brytyjski niejako programowo zakładał, że nasze zdroworozsądkowe myślenie, pojęcia i kategorie nie są odpowiednimi narzędziami do uprawiania filozofii.

57 Jak zauważa Platon, gdy opisuje naturę filozofa: „Nie ma nic bardziej przeciwnego takiej duszy, jak drobiazgowość; duszy, która się zawsze chce garnąć do całości, do ogółu w sprawach boskich i ludzkich". Zob. Platon, Państwo, przeł. Władysław Witwicki (Kęty: Antyk, 2003), 189. 
w swej książce Stowa i rzeczy ${ }^{58}$. Ów brak spełniania pokładanych w filozofii analitycznej nadziei wyraża również Arthur Danto, stwierdzając: „,[...] Doszedłem do przekonania, że filozofia analityczna stała się sterylna i zrytualizowana. Przedstawiano w zapisie logicznym rzeczy, które mogły być wyrażone zupełnie dobrze bez zapisu logicznego. W ten sposób prezentowało się kolegom umiejętność wykonywania takich działań. Wszystko to nie miało żadnego znaczenia [...]. Napotykam [obecnie] jedynie artykuły z filozofii analitycznej, które generują problemy wydające się marginalne wobec tego wszystkiego, czym ktokolwiek poza kręgiem dyskutantów mógłby być zainteresowany" 59 .

Możemy obecnie obserwować powrót do filozofii w jej klasycznym paradygmacie i problematyki typowo metafizycznej. I choć należy również przyznać, że ten nurt filozofii nie jest obecnie dominujący, to jednocześnie nie można owego zjawiska bagatelizować. Powrót ten, nazywany przez niektórych zwrotem metafizycznym, nawiązując do tzw. zwrotu lingwistycznego, wydaje się niejako potwierdzać tezę brytyjskiego filozofa o tym, że my sami jako ludzie ze swej natury nie możemy i nie potrafimy uciec od całościowego myślenia o świecie. Wśród myślicieli, którzy pozostali wierni klasycznej wizji filozofii, należy wspomnieć o Johnie Fosterze, który wprost nawiązywał do Berkeleyowskiej wersji idealizmu ${ }^{60}$, Timothym Sprigge'u, który w swej myśli odwoływał się do filozofii Bradleya, broniąc swej autorskiej wersji idealizmu absolutnego ${ }^{61}$, czy Michaelu Della Rocca $^{62}$. W ostatnich latach obok wzrostu zainteresowania problematyką metafizyczną możemy również zauważyć odnowienie się zainteresowania myślą samego Bradleya, jak i innych idealistów brytyjskich, takich jak Thomas H. Green czy Bernard Bosanquet ${ }^{63}$. W perspektywie myśli

58 Zastanawiający jest fakt, że przedmowę do książki Gellnera napisał nie kto inny jak Russell. W przedmowie tej pomstuje on na oksfordzkich filozofów redukujących całą problematykę filozoficzną do pewnego nieporozumienia językowego, jakby nie zdając sobie sprawy z tego, jakiej proweniencji są to poglądy.

59 Zob. Arthur Danto, Peter Osborne, „Sztuka i analiza”, przeł. Ewa D. Bogusz, Sztuka i Filozofia 25 (2004): 9.

60 Swe dzieło World for Us dedykuje on właśnie Berkeleyowi. Zob. John Foster, A World for Us: The Case for Phenomenolistic Idealism (New York: Oxford University Press, 2008).

61 Zob. Timothy Sprigge, The Vindication of Absolute Idealism (Edinburgh: Edinburgh University Press, 1983).

62 Michael Della Rocca, Parmenidean Ascent (New York: Oxford University Press, 2020).

63 Na uwagę zasługuje tu szczególnie pozycja British Idealism: A History. Zob. William Mander, British Idealism: A History (New York: Oxford University Press, 2011). Jeśli chodzi o myśl Bradleya, to wydaje się, że szczególnym zainteresowa- 
Bradleya ów powrót wydaje się czymś naturalnym. Potrzeba uprawiania metafizyki wypływa bowiem wprost z ludzkiej natury i nie możemy tego zignorować.

W takiej optyce okazuje się, że również egzystencjalny zwrot, jaki nastąpił $\mathrm{w}$ ramach filozofii kontynentalnej, zwrot, który miał w przeciwieństwie do tradycyjnej metafizyki otworzyć się na człowieka i jego egzystencję, zignorował najwznioślejszą i najbardziej ludzką część naszej natury ${ }^{64}$. Ostatecznie stajemy przed faktem, że od samej metafizyki nie możemy uciec. Wszelkie postulowanie końca metafizyki czy choćby nawet najbardziej radykalny sceptycyzm okazują się niczym innym jak samą metafizyka, przykrytą jedynie pustym wielosłowiem. Nawet gdyby sama metafizyka kończyła się tylko sceptycyzmem, to mimo to byłaby ona warta tego, by ją uprawiać. Koniec metafizyki bowiem oznaczałby jednocześnie koniec człowieczeństwa:

[...] Kiedy poczucie tajemnicy, jej czar, nie będzie już przyciągał[o] umysłu, by błądził myślą bez celu i darzył miłością nie wiedzieć co; gdy, krótko mówiąc, brzask i zmierzch nie będą już miały uroku - dopiero wówczas metafizyka będzie bezwartościowa ${ }^{65}$.

\section{Bibliografia}

Allard James. 2004. The Logical Foundations of Bradley's Metaphysics: Judgment, Inference, and Truth. New York: Cambridge University Press.

Ayer Alfred. 1936. Language, Truth and Logic. London: Victor Gollancz Ltd.

Baldwin Thomas. 1984. „Moore's Rejection of Idealism”. W: Philosophy in History:

Essays on the Historiography of Philosophy, red. Richard Rorty, Jerome B. Schnee-

wind, Quentin Skinner, 357-374. Cambridge: Cambridge University Press.

Berkeley George. 2002. Trzy dialogi między Hylasem a Filonousem, przeł. Janina Sosnowska. Kęty: Antyk.

Bradley Francis Herbert. 1914. „A Discussion of Some Problems in Connexion

niem cieszą się jego badania nad logiką. Zob. James Allard, The Logical Foundations of Bradley's Metaphysics: Judgment, Inference, and Truth (New York: Cambridge University Press, 2004); Anthony Manser, Bradley's Logic (Oxford: B. Blackwell, 1983); Phillip Ferreira, Bradley and the Structure of Knowledge (Albany: State University of New York Press, 1999).

64 Jak już wspomniano, Lévinas myślał zgoła inaczej. Uważał on, że metafizyka jest czymś, co jako ludzie powinniśmy przezwyciężyć. Szczególną niechęcią Lévinas darzył Parmenidesa z Elei i, jako ojca metafizyki, obarczał go winą za powstanie „kultury immanencji”. Por. Dariusz Kubok, „Emmanuela Lévinasa krytyka filozofii Parmenidesa", Folia Philosophica 21 (2003).

65 Bradley, Zjawisko, 3. 
With Mr. Russell's Doctrine". W: Francis Herbert Bradley, Essays on Truth and Reality, 293-309. Oxford: Clarendon Press.

Bradley Francis Herbert. 1916. Appearance and Reality. London: George Allen \& Unwin Ltd.

Bradley Francis Herbert. 1996. Zjawisko a rzeczywistość, przeł. Jerzy Szymura. Torun: Comer.

Candlish Stewart. 2007. Russell-Bradley Dispute and its Significance for Twentieth Century Philosophy. New York: Palgrave Macmillan.

Danto Arthur, Osborne Peter. 2004. „Sztuka i analiza”, przeł. Ewa D. Bogusz. Sztuka i Filozofia 25: 5-20.

Ferreira Phillip. 1999. Bradley and the Structure of Knowledge. Albany: State University of New York Press.

Foster John. 2008. A World for Us: The Case for Phenomenolistic Idealism. New York: Oxford University Press.

Gallop David. 1991. Parmenides of Elea. Toronto-Buffalo-London: University of Toronto Press.

Golichowski Janusz. 1965. „Francis Herbert Bradley a problem wewnętrznych i zewnętrznych relacji". Gdańskie Zeszyty Humanistyczne 8: 173-185.

Green Thomas Hill. 1889. „Faith”. W: Works of Thomas Hill Green, t. 3, red. Richard Lewis Nettleship, 253-276. London: Longmans, Green, and Co.

Green Thomas Hill. 1889. „Popular Philosophy in Its Relation to Life”. W: Works of Thomas Hill Green, t. 3, red. Richard Lewis Nettleship, 92-125. London: Longmans, Green, and Co.

Grygieńć Janusz. 2009. Thomas Hill Green: od epistemologii do filozofii politycznej. Toruń: Europejskie Centrum Edukacyjne.

Heidegger Martin. 1976. „Koniec filozofii i zadanie myślenia”, przeł. Krzysztof Michalski. Teksty: Teoria Literatury, Krytyka, Interpretacja 4-5 (28-29): 9-26.

Heidegger Martin. 1997. „Czym jest metafizyka? - wprowadzenie”, przeł. Krzysztof Wolicki. W: Budować, mieszkać, myśleć, red. Krzysztof Michalski, 27-47. Warszawa: Czytelnik.

Hume David. 1977. Badania dotyczace rozumu ludzkiego, przeł. Jan Łukasiewicz i Kazimierz Twardowski. Warszawa: PWN.

Hylton Peter. 1992. Russell, Idealism, and the Emergence of Analytic Philosophy. Oxford: Clarendon Press.

James William. 1958. Doświadczenia religijne, przeł. Jan Hempel. Warszawa: Książka i Wiedza.

Kahn Charles H. 2009. „Being in Parmenides and Plato”. W: Charles H. Kahn, Essays on Being, 167-191. New York: Oxford University Press.

Kant Immanuel. 1986. Krytyka czystego rozumu, t. 1, przeł. Roman Ingarden. Warszawa: PWN.

Kubok Dariusz. 2003. „Emmanuela Lévinasa krytyka filozofii Parmenidesa”. Folia Philosophica 21: 129-137.

Mander William. 2011. British Idealism: A History. New York: Oxford University Press. 
Manser Anthony. 1983. Bradley's Logic. Oxford: B. Blackwell.

McHenry Leemon B. 1992. Whitehead and Bradley: A Comparative Analysis. Albany: State University of New York Press.

McTaggart John McTaggart Ellis. 1906. Some Dogmas of Religion. London: Edward Arnold.

Muirhead John Henry. 1924. Contemporary British Philosophy: Personal Statements. London: George Allen and Unwin.

Passmore John. 1917. A Hundred Years of Philosophy. London: Duckworth Books. Platon. 2003. Państwo, przeł. Władysław Witwicki. Kęty: Antyk.

Reale Giovanni. 2008. Historia filozofii starożytnej, t. 1, przeł. Edward Iwo Zieliński. Lublin: KUL.

Rocca Michael Della. 2017. „Bradley's Appearance and Reality”. W: Ten Neglected Classics of Philosophy, red. Eric Schliesser, 120-147. New York: Oxford University Press.

Rocca Michael Della. 2020. Parmenidean Ascent. New York: Oxford University Press. Russell Bertrand. 1910. „The Monistic Theory of Truth”. W: Bertrand Russell, Philosophical Essays, 150-169. London: Green \& Co.

Saxena Sushil Kumar. 1967. Studies in the Metaphysics of Bradley. London: George Allen \& Unwin Ltd.; New York: Humanities Press Inc.

Schelling Friedrich Wilhelm Joseph. 2015. System idealizmu transcendentalnego, przeł. Krystyna Krzemieniowa. Warszawa: Wydawnictwo Naukowe PWN.

Skarga Barbara. 1997. „Emmanuel Lévinas: kultura immanencji”. W: Barbara Skarga, Tożsamość i różnica, 92-113. Kraków: Znak.

Sprigge Timothy. 1983. The Vindication of Absolute Idealism. Edinburgh: Edinburgh University Press.

Szubka Tadeusz. 2011. „Główne typy metafizyki analitycznej”. Filo-Sofija 15 (4): 849-864.

Szymura Jerzy. 1990. „O tym, jak Bertrand Russell rozprawił się z absolutnym monizmem". Studia Filozoficzne 2-3: 267-280.

Szymura Jerzy. 1990. Relacje w perspektywie absolutnego monizmu F. H. Bradleya. Kraków: nakł. Uniwersytetu Jagiellońskiego.

Wyrębska Ewa. 2010. „Idea metafizyki w filozofii Immanuela Kanta”. Diametros 23: $162-181$.

\section{Streszczenie}

Celem artykułu jest analiza argumentacji, jaką sformułował w obronie metafizyki Francis Herbert Bradley we wstępie swego głównego dzieła Appearance and Reality. Oksfordzki filozof, będąc jednym z ostatnich znaczących przedstawicieli systemowej filozofii, był świadom tego, że epoka, w jakiej przyszło mu żyć i tworzyć, była epoka, w której podawano w wątpliwość zasadność czy wartość metafizyki rozumianej jako teoria pierwszych zasad. W swej obronie metafizyki Bradley poddaje krytyce argumentację antymetafizyczna, którą nie bez podstaw możemy 
wiązać z myślą Kanta i Hume'a. Wskazuje on również, niejako uprzedzając XX-wieczną krytykę systemowej filozofii, że nie jest ona źródłem dogmatyzmu, lecz raczej jako krytyczna refleksja nad naszymi pojęciami jest w istocie „azylem dla kogoś, kto bardzo chce myśleć spójnie, a jest zbyt zdolny i autentyczny, by stać się niewolnikiem tępego fanatyzmu lub nieuczciwej sofistyki".

Słowa kluczowe: idealizm, metafizyka, Francis Herbert Bradley, monizm, neoheglizm

\section{Summary}

\section{Francis Herbert Bradley's Defence of Metaphysics}

The aim of the article is to analyse the arguments formulated in defence of metaphysics by Francis Herbert Bradley in the introduction to his main work Appearance and Reality. The Oxford philosopher, being one of the last significant representatives of systemic philosophy, was aware that the era in which he had to live and create was an era in which the validity or value of metaphysics, understood as the theory of first principles, was questioned. In his defence of metaphysics, he criticizes the anti-metaphysical argumentation which we can associate, not without reason, with the thought of Kant and Hume. He also points out, somewhat ahead of the twentieth-century critique of systemic philosophy, that it is not a source of dogmatism, but rather, as a critical reflection on our concepts, it is in fact "a refuge for the man who burns to think consistently, and yet is too good to become a slave, either to stupid fanaticism or dishonest sophistry".

Keywords: idealism, metaphysics, Francis Herbert Bradley, monism, neo-Hegelianism 